\title{
Bioeconomic impact of bull breeding soundness examination in cow-calf systems
}

\section{Sílvio Renato Oliveira Menegassi ${ }^{1}$, Júlio Otávio Jardim Barcellos ${ }^{2}$, Vinícius do Nascimento Lampert $^{3}$, João Batista Souza Borges ${ }^{4}$, Vanessa Peripolli ${ }^{1}$}

\footnotetext{
1 Programa de Pós-Graduação em Zootecnia - Universidade Federal do Rio Grande do Sul (UFRGS), Porto Alegre - RS, Brasil.

2 Departamento de Zootecnia-NESPRO/UFRGS. Pesquisador do CNPq.

${ }^{3}$ Universidade Estadual de Mato Grosso do Sul (UEMS), Bolsista Fundect, Programa de Pós-Graduação em Zootecnia - UFRGS.

${ }^{4}$ Departamento de Medicina Animal - UFRGS.
}

\begin{abstract}
It was evaluated the bioeconomic impact of the breeding soundness evaluation on beef cattle production in southern Brazil. Two similar production systems, with and without the use of breeding soundness evaluation, were compared during 4 years in the municipality of Júlio e Castilhos. The rate of unsound bulls in the first examination was $22.8 \%$. By performing the examination, calf production increased by 31\%, 13.8 calves/bull/year and $24 \mathrm{~kg}$ of calves/cow/year. The benefit/cost ratio on the investment with the breeding soundness evaluation was $\mathrm{R} \$ 35.84$. The breeding soundness evaluation improves bioeconomic aspects of beef cow-calf systems.
\end{abstract}

Key Words: beef cattle, efficiency, fertility, productivity

\section{Impacto bioeconômico do exame andrológico de touros em sistemas de cria}

RESUMO - Avaliou-se o impacto bioeconômico do exame andrológico na produção de bovinos de corte no Sul do Brasil. Foram comparados dois sistemas de produção similares com e sem a adoção do exame andrológico durante quatro anos no município de Júlio e Castilhos. A taxa de touros inaptos no primeiro exame foi de 22,8\%. Com a realização do exame, obteve-se aumento de 31\% na produção de bezerros, 13,8 bezerros/touro/ano e $24 \mathrm{~kg}$ de bezerros/vaca/ano. A relação benefício/custo sobre o investimento com o exame andrológico foi de R\$35,84. O exame andrológico melhora os aspectos bioeconômicos de sistemas de cria de bovinos de corte.

Palavras-chave: eficiência, fertilidade, pecuária de corte, produtividade

\section{Introduction}

Beef production systems in the state of Rio Grande do Sul, as well as in the major beef production regions in Brazil, still exhibit low productivity compared to other production regions in the world: the weaning rate amounts to approximately $55 \%$, the percentage of bulls is $3.8 \%$, natural mating is used by more than $90 \%$ of breeders and only $10.5 \%$ perform breeding soundness examination (BSE) as an annual routine practice (UFRGS, 2005). Nutritional and health problems found in the herd, combined with the presence of infertile bulls, are a setback to the improvement of bioeconomic performance and result in low reproductive efficiency (Trenkle \& Willham, 1977).

To improve the efficiency of cow-calf production systems it is necessary to increase the weaning rate, calf weight and cull cow weight, and to reduce age at first calving (Beretta, 2001). It has to be observed that reproductive efficiency is even more dependent on the bull when cows show a high rate of ovarian cyclicity.

In this scenario, the importance of bulls is quite clear, inasmuch as they account for over $90 \%$ of the genetics of the herd, even though they represent only $5 \%$ of it. In their useful life, they can sire from 100 to 300 calves, depending on the bull:cow ratio and on pregnancy rates during this period (Amaral et al., 2003). Because most breeders lack information about the fertility of their bulls, the identification of these animals and the causes for culling are of utmost importance as these bulls might not be identified before the end of the breeding season, leading to a large number of barren cows (Amann et al., 2000).

BSE allows the obtaining of information about the potential fertility of bulls, and its importance has been reported by several authors such as Lagerloff (1936), Silva et al. (1981), Fonseca et al. (1997), Moraes et al. (1998), Menegassi et al. (2008) and Lopes et al. (2009). 
However, the economic advantages of bull BSE prior to the breeding season still have to be further investigated, because the current studies about bioeconomic impact of technologies are related mainly to beef heifers (Pfeifer et al., 2008) and few of them relate the use of technology with the BSE in bulls.

The interest in this investigation came from the observation of the results of the Programa de Avaliação de Touros - PAAT in Júlio de Castilhos, a town in the state of Rio Grande do Sul (RS). The observations indicated some improvement in pregnancy rates on farms that used BSE (Menegassi \& Vieira, 2006). Therefore, the objective of this study was to determine the bioeconomic impact of breeding soundness evaluation on cow-calf systems in order to check its importance as a management practice that may improve the productive and economic efficiency of the herd.

\section{Material and Methods}

To assess the biological and economic impact of BSE on cow-calf farms, similar systems used in the same region in Rio Grande do Sul were compared in terms of reproductive efficiency. Therefore, the characteristics of two groups of farms in the sanitary zone II in Júlio de Castilhos were analyzed from 1998 to 2001. The first group, hereafter referred to as SAN, did not use BSE whereas the second group, named CAN, adopted the examination as a management practice during the study period. The herd of these groups had around 5,000 cows and 170 bulls, representing $35 \%$ of the herd of the investigated region.

The production systems were similar, using natural pastures, which basically consisted of grasses such as Paspalum notatum and other species belonging to the genus Paspalum, Aristida pallens, and Andropogon lateralis. These grasses were predominantly found in the region investigated.

Most cows were Charolais or Charolais cross, pluriparous and non-suckling to which similar health, nutritional and reproductive management practices were applied. The only difference among them was the BSE in the experimental groups. Bulls were Aberdeen Angus, Hereford, Charolais, Devon, Limousin and Nelore breeds, with ages ranging from 2 to 10 years, and they had never been submitted to BSE.

Information such as bull culling rate was obtained from the PAAT. The guidelines for BSE were those recommended by the Colégio Brasileiro de Reprodução Animal (CBRA, 1998) for unrestrained bulls to identify the soundness or unsoundness of bulls. BSE is based on the observation of general health, genital health, physical ability, libido and sperm viability.

The information that determines the bioeconomic impact of both groups was obtained from field data, economic data, PAAT data and estimations described in the literature. The prices realized between the spring of 2008 and fall of 2009 were used. The monetary values were converted from reais (R\$) to U.S. dollars (US\$), considering that 1 dollar is equivalent to 1.85 reais.

The field data and PAAT data were the following:

a) BCw - bull:cow ratio; b) number of bulls (B), cows $(\mathrm{Cw})$ and calves (C) in the herd; c) UB1 - rate of unsound bulls in the first year (\%); d) UB2 - average rate of unsound bulls in other years (\%); e) SBY - service bulls per year (heads);f) P - prolificacy (\%): quotient between the number of calves and the number of beef cows on the farm in February of each year. Although the weaning rate is more usual, it was not used in this study because the data were collected in February and calves had already been born, but had not been weaned yet.

The economic data were as follows:

a) BPr - bull purchasing price (US\$): average price realized in the local market; b) PrBEUL - price of bull at the end of useful life (US\$): average price realized in the region for the sale of fattened cattle; c) CPr - price of live weight of calf (US\$/live weight): price realized in the local market; d) BSEC-BSE cost(US\$); e) MC-bull maintenance cost(US\$): average cost in the region; f) $\mathrm{i}$ - annual interest rate (\%);

The following variables were estimated:

a) Ckg - calf weight (kg): average weight of $150 \mathrm{~kg}$; b) UL - useful life of bulls (years): the useful life of bulls estimated by the analysis of PAAT data amounted to 4 years. Because there is not enough publications on the useful life of bulls, it was considered to be 6.2 and 4 years for the SAN and CAN groups, respectively, and it was assumed that the demand for bulls over the years is identical for both groups; b) AD - annual demand for bulls. The demand depends on the number of bulls and on the culling rate (SBY * AC). The demand is identical for both groups. The UL value of the SAN group was used, which equates the demand of both groups.

The information on biological and economic characteristics of the herd was embedded into spreadsheets using the following data and estimations:

a) AC - annual culling (\%): bulls are culled for diseases, bone fractures, risk of consanguinity, sale, death and bull unsoundness in the BSE. Annual culling is the combination of year-round culling (YRC) and culling in the BSE (UB1 and UB2). It is the inverse of useful life (AC $=1 / \mathrm{UL})$; b) YRC year-round culling (AC - UB2); c) IRUB - implicit rate of 
unsound bulls: percentage of unsound bulls in the SAN group obtained from examination of the CAN group, based on the assumption that the percentage of unsound bulls is the same for both groups; d) UB - unsound herd bulls (SBY*IRUB); e) FBCw - fertile bull:cow ratio: subtraction of the number of unsound bulls detected in the examination $(\mathrm{Cw} /(\mathrm{SBY}-\mathrm{UB}))$; f) $\mathrm{CP}$ - annual calf production $\left(\mathrm{CW}^{*} \mathrm{P}\right)$; g) BPUL - bull production ((CP/SBY)*UL): total amount of calves sired per bull during its useful life; $\mathrm{h}$ ) $\mathrm{BP}$ - annual bull production (CP / SBY); i) CwP - annual cow production ((CP $\left.\left.\left.{ }^{*} \mathrm{Ckg}\right) / \mathrm{Cw}\right) ; \mathrm{j}\right) \mathrm{CPV}$ - calf production value $(\mathrm{CP} * \mathrm{CPr} * \mathrm{Ckg})$; k) PPSB - potential value for the purchase of superior bulls (BPr+ BSER/SBY);

It was checked if the nominal increase in calf production shown by prolificacy was a random event or if it occurred because of the use of BSE. The analysis of variance was used to check if the variability between groups was higher than within groups at $5 \%$ of probability. The hypothesis that prolificacy for 1998, when the examination was adopted, is equal to the cumulative average for subsequent years (1999, 2000 and 2001) was tested. The Student's t test was used for comparison among the means and the confidence interval was also used because it provided additional information to the Student's t test. The confidence interval estimates the true difference between two means at a given probability (95\%).

In a cow-calf production system, the impact of reproductive assessment on bulls is verified by the magnitude of fluctuations in reproductive parameters, especially by prolificacy, altering other biological indicators (Tables 1 and 2). The 95\% confidence interval was used to establish the lower and upper bounds of prolificacy and the mean of these bounds was used as the basis for the estimation of the bioeconomic impact of BSE.

To standardize the results on different farms, two farms with 1,000 cows were considered. The bioeconomic impact was obtained by the partial budgeting method described by Noronha (1987), which allowed to obtain expressions that could represent the increase in revenue (1), reductions in costs (2), reductions in revenues (3) and increase in costs (4). However, in this study, there were no reductions in revenues. The relationships between data, information and impact measurements were organized using an Excel spreadsheet. To obtain the bioeconomic impact measurements, a total of 22 expressions were used in order to sort out the existing relationships.

The general expression that guides our analysis is the net BSE revenue (BSER), which is expressed as follows: BSER $=$ Ckgcan $\times$ CPrcan $\times$ CPcan $-($ Ckgsan $\times$ CPrsan $\times$ CPsan $)+($ ULsan - ULcan $) \times$ PrBEULcan $\times$ ADcan $\times \mathrm{i}+$
$($ SBYsan - SBYcan) $\times$ MCcan - BSEC $\times$ SBYcan. The establishment of the relationships among data, information and measurements of impacts on this production system underscores the complexity of animal husbandry systems, as described by Black (1993).

The present study proposes an approach to assess the bioeconomic impact across cow-calf systems that use and do not use the BSE (Table 3).

Table 1 - Prolificacy and descriptive statistics of the SAN group

\begin{tabular}{lcccc}
\hline & 1998 & 1999 & 2000 & 2001 \\
\hline Farm 1 & 0.33 & 0.40 & 0.44 & 0.43 \\
Farm 2 & 0.54 & 0.65 & 0.62 & 0.47 \\
Farm 3 & 0.79 & 0.81 & 0.67 & 0.68 \\
Farm 4 & 0.44 & 0.49 & 0.58 & 0.59 \\
Farm 5 & 0.40 & 0.43 & 0.47 & 0.63 \\
Farm 6 & 0.42 & 0.42 & 0.58 & 0.52 \\
& \multicolumn{4}{c}{} \\
Median sescriptive statistic & & \\
Sstandard deviation & 0.43 & 0.46 & 0.58 & 0.56 \\
Coefficient of variation (\%) & 0.16 & 0.16 & 0.09 & 0.09 \\
Mean & $33 \%$ & $31 \%$ & $16 \%$ & $17 \%$ \\
& 0.49 & 0.53 & 0.56 & 0.55 \\
\hline
\end{tabular}

Table 2 - Prolificacy and descriptive statistics of the CAN group

\begin{tabular}{lcccc}
\hline & 1998 & 1999 & 2000 & 2001 \\
\hline Farm 7 & 0.41 & 0.64 & 0.64 & 0.61 \\
Farm 8 & 0.49 & 0.64 & 0.70 & 0.73 \\
Farm 9 & 0.58 & 0.64 & 0.69 & 0.71 \\
Farm 10 & 0.47 & 0.59 & 0.62 & 0.76 \\
Farm 11 0.56 & 0.71 & 0.79 & 0.58 \\
Farm 12 & 0.60 & 0.69 & 0.69 & 0.73 \\
& \multicolumn{4}{c}{ Descriptive statistic } \\
Median & 0.52 & 0.64 & 0.69 & 0.72 \\
Standard deviation & 0.07 & 0.04 & 0.06 & 0.07 \\
Coefficient of variation (\%) & $14 \%$ & $7 \%$ & $9 \%$ & $11 \%$ \\
Mean & 0.52 & 0.65 & 0.69 & 0.69 \\
\hline
\end{tabular}

\section{Results and Discussion}

The SAN group did not show any significant differences in prolificacy at 5\% from 1998 to 2001. This shows that prolificacy did not vary among farms in the analyzed years when similar production conditions were utilized.

Although there were climatic variations across the years, which affected productivity, all farms were submitted to the same adverse conditions and consequently had similar prolificacy.

The same does not apply to the CAN group, in which prolificacy showed significant difference $(\mathrm{P}<0.05)$ between the first year of the examination (1998) and the other years (1999, 2000 and 2001). The effect of BSE was observed on 
Table 3 - Approach suggested for the estimation of the bioeconomic impact of bull BSE on cow-calf systems

\begin{tabular}{|c|c|c|c|}
\hline \multicolumn{4}{|c|}{ Biological impact } \\
\hline ICP & Calf production & (CPcan - CPsan) / CPcan & $\%$ \\
\hline ICwP & Annual cow production & CwPcan - CwPsan & calf weight/cow/year \\
\hline \multicolumn{4}{|c|}{ Economic impacts } \\
\hline IRB & Net revenue per bull & BSER / SBYcan & US\$/bull/year \\
\hline BCR & Benefit/cost ratio & BSER / OBSEC & US\$ \\
\hline \multicolumn{4}{|c|}{ Partial budgeting } \\
\hline IRa & Increase in revenue from calves & $\begin{array}{l}\text { Ckgcan } \times \text { CPrcan } \times \text { CPcan }- \\
(\text { Ckgsan } \times \text { CPrsan } \times \text { CPsan })\end{array}$ & US\$ \\
\hline OBSEC & Overall BSE cost & BSEC $\times$ SBYcan & US\$ \\
\hline
\end{tabular}

calf production. The confidence interval revealed that the estimation of the true difference for mean prolificacy across farms which did and did not perform BSE corresponds to 0.0532 for the lower bound and to 0.2657 for the upper bound. Because zero does not belong to this interval, there is a significant difference in it.

In percentage terms, the prolificacy of a herd submitted to BSE can increase from 5.32 to 26.57 percentage points. The prolificacy of the SAN group was 0.52 and that of the CAN group was 0.68 . To perform economic analysis, a 16-percentage-point increase in prolificacy was considered because this is the mean for the confidence interval limits for years 1999 to 2001. Oliveira (2002) estimated an increase of 13 percentage points from the use of the bull BSE. The fluctuations in prolificacy are not caused by random factors, but by the influence of the bull breeding soundness examination.

Blockey (1984) demonstrated that the adoption of the BSE increased the mean calving rates from 85 to $91 \%$, and among cows which calved the first weeks, the rate went up from 66 to 77\%. This lower rate obtained by Blockey (1984) might be explained by higher pregnancy rates than those observed in the herd analyzed herein.

The bull:cow ratio was 1:26 in the SAN group and 1:40 in the CAN group. The rate of unsound bulls observed in the BSE corresponded to $22.8 \%$ in the first year (UB1) and to $15 \%$ in the mean for the remaining years (UB2). Since the SAN group was not submitted to BSE, an implicit rate of unsound bulls equivalent to that obtained in the CAN group (IRUB) was used for comparison. UB1 is the value that would be obtained from the first evaluation of bulls.
UB2 is the value that represents the stabilized rate for the remaining years.

Annual culling when BSE is not used corresponds to $16.7 \%$. This replacement refers to explicit problems detected without BSE, such as evident physical limitations, age, consanguinity or other reasons specified by the cattle farmer.

The culling rate for the CAN group was 25\%. The culling was quicker because of the detection of problems with bulls was earlier than in the SAN group. Therefore, the adoption of BSE may reduce the proportion of bulls and increase the culling rate, thus reducing the time during which a bull is maintained in the herd.

These rates were calculated from the estimate of 6.2 and 4 years of useful life for the SAN and CAN group, respectively. The economic data between the two groups were the same except for the cost of the BSE and the interest rate. The value for the purchase of bulls amounted to US\$ 2,753.97. The purchase value of fattened bulls was US\$ 1,027.02. Calf price was US\$1.44 per kg of calf. The annual bull maintenance cost was US\$ 216.21 and the interest rate for the calculation of the capital and opportunity cost corresponded to $6 \%$ p.a. This interest rate was used to compare the sale of bulls at different times.

The data were processed using the relationships established in Material and Methods, providing technical and economic information, as described in Table 5. The number of cows per fertile bull was 33 for the SAN group and 40 for the CAN group (Table 4). The demand corresponds to 6.3 bulls per year for both groups. Under these conditions, calf production increases by 160 calves for a herd with 1,000 cows, and by 26 calves per bull during its useful life. Annual 
bull production in the CAN group was 27.2 calves while the annual cow production was $102 \mathrm{~kg}$ of calves per year. The calf production value for the CAN group was estimated at US\$147,762.16.

Based on the available data and information, the partial budgeting (Table 6) was obtained, consisting of the comparison of farms that use and those that do not use the BSE.

The sale value of bulls culled based on BSE results is not included as revenue in the partial budgeting. Actually, there is an anticipated cash flow entry for the farm within 1.8 years because with the BSE the useful life of bulls decreased from 6.2 to 4 years. An increase in revenue is derived from the interest obtained from the anticipated financial value of the sale of cull bulls at $6 \%$ p.a.

The use of BSE increased calf production by $31 \%$; an increase in the production of each bull is estimated at 13.8 additional calves during the useful life of the bull and additional $24 \mathrm{~kg}$ of calves per year for cows.
The net revenue was US\$ 37.54 per cow and US\$ $1,501.71$ per bull. The net revenue for a herd with 1,000 cows was US\$37,542.97. The benefit/cost ratio of the BSE corresponded to US\$19.37 (Table 7).

The BSE biologically and economically benefits the beef production system. Even though the benefit was calculated for a 16-percentage-point in prolificacy, if it increased by only 1 percentage point the financial advantages would still be greater than the costs of BSE.

The cost of BSE is considered low in relation to its benefit. In this study, a benefit/cost ratio similar to that found by Chenoweth et al. (2002) was obtained, corresponding from US\$ 20 to US\$25, and by Oliveira (2002), which was equivalent to US\$19.67. Although the bioeconomic impact caused by the use of BSE is large, only $10.5 \%$ of breeders in the state of Rio Grande do Sul employ this type of examination. This leads to the following question: why don't some breeders use this technology considering that is bioeconomically efficient? The identification of

Table 4 - Standardized biological and economic data and estimates for a herd with 1,000 cows for the SAN and CAN groups

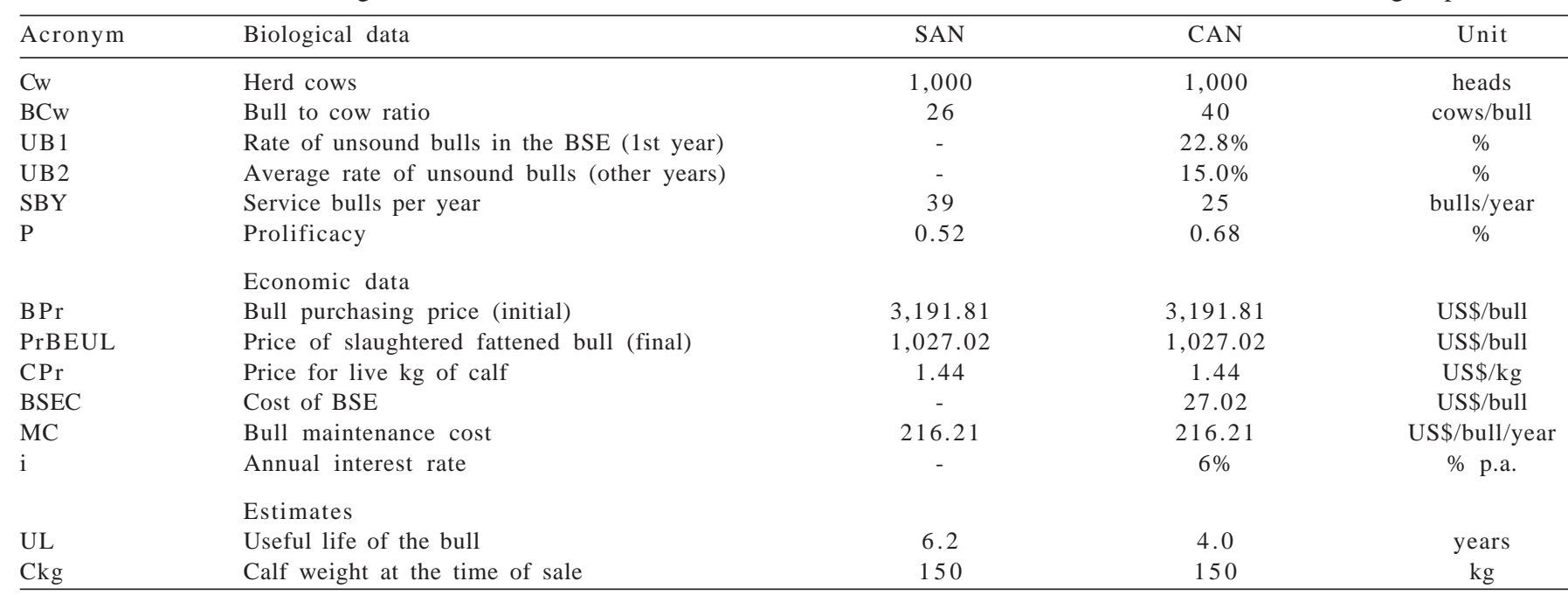

Table 5 - Standardized biological and economic data for a herd with 1,000 cows for the SAN and CAN groups

\begin{tabular}{|c|c|c|c|c|}
\hline Acronym & Biological data & SAN & CAN & Unit \\
\hline $\mathrm{AC}$ & Annual culling & $16.1 \%$ & $25.0 \%$ & $\%$ \\
\hline YRC & Year-round culling & - & $10.0 \%$ & $\%$ \\
\hline IRUB & Implicit rate of unsound bulls & $22.8 \%$ & - & $\%$ \\
\hline FBCw & Fertile bull:cow ratio & 33 & 40 & cows/bull \\
\hline $\mathrm{AD}$ & Annual demand for bulls & 6.3 & 6.3 & bulls/year \\
\hline $\mathrm{CP}$ & Annual calf production & 520 & 680 & calf/year \\
\hline \multirow[t]{2}{*}{ CwP } & Annual cow production & 78 & 102 & kg calf/cow/year \\
\hline & Economic data & & & \\
\hline $\mathrm{CPV}$ & Calf production value & $112,994.59$ & $147,762.16$ & US\$ \\
\hline PPSB & Potential value for purchase of superior bulls & - & $4,693.52$ & US\$/bull \\
\hline
\end{tabular}


Table 6 - Partial budgeting with the use of bull BSE

\begin{tabular}{llcc}
\hline Acronym & Partial budgeting & Impact & Value (US\$) \\
\hline & Increase in revenue (+): & + & $34,767.56$ \\
IRa & Increase in revenue from calves & + & 847.89 \\
IRb & Interests obtained with anticipated sale of cull bulls & + & $2,975.07$ \\
& Cost reduction (+): & - & $1,047.55$ \\
RBC & Reduction in bull maintenance cost & & 0.00 \\
OBSEC & Increase in cost (-): & + & $37,542.97$ \\
RR & Overall BSE cost & + \\
BSER & Reduction in revenue (-): & & \\
\hline
\end{tabular}

Table 7 - Technical and economic impact measurements of BSE for a herd with 1,000 cows

\begin{tabular}{llccc}
\hline & Biological impact & Effect & Value & Unit \\
\hline ICP & Calf production & + & $31 \%$ & $\%$ \\
IBP & Annual bull production & + & 13.8 & calf/bull/year \\
ICwP & Annual cow production & + & 24.0 & calf weight (kg)/cow/year \\
& Economic impact & & & \\
IRCW & Net revenue per cow & + & 37.54 & US\$/cow/year \\
IRB & Net revenue per bull & + & $1,501.71$ & US\$/bull/year \\
BSER & Total net BSE revenue & + & $37,542.97$ & US\$ \\
BCR & Benefit/cost ratio of the BSE & + & 19.37 & US\$ \\
\hline
\end{tabular}

factors that hinder the development of this sector could guide the design and implementation of agricultural policies targeted at agribusiness in Brazil.

BSE is an economically feasible technology which, combined with other changes in management practices, may improve revenues of breeders. Sereno et al. (2002), Fonseca (2000) and Franco et al. (2006) found a benefit/cost ratio of US\$ 8.24, US\$12.32 and US\$13.83, respectively. These values were obtained from the change in the rate of herd bulls based on the use of bulls whose reproductive efficiency could be ascertained. The adjustment of the bull:cow ratio for Brazilian production systems is a measure that can enhance the economic benefits of BSE.

Another benefit of BSE is that, with the increase in net revenue, breeders can purchase other bulls through selffinancing. In this study, the increase in net revenue per bull was equivalent to US $\$ 1,501.71$, accounting for nearly $50 \%$ of a new bull at the price of US\$3,191.81. The increasing cost of bull price may be a hindrance to the purchase of superior bulls; however, the increase in net revenues with the use of BSE may provide breeders with incentives and resources to invest in the genetic improvement of their herds.

\section{Conclusions}

Breeding soundness examination has a positive effect on bioeconomic variables in cow-calf systems. It is a lowcost management practice and, even though it is not widely adopted by breeders in the state of Rio Grande do Sul, it is an important technological alternative that helps increase beef cattle production in the state. This examination allows breeders to increase calf production and, consequently, their revenues, with positive impacts on other links of the beef production chain. The partial budgeting method proposed here can be used by or adapted to other research studies for the assessment of the bioeconomic impacts of breeding soundness examination.

\section{References}

AMANN, R.P.; SEIDEL JUNIOR, G.E.; MORTIMER, R.G. Fertilizing potential in vitro of semen from young beef bulls containing a high or low percentage of sperm with a proximal droplet. Theriogenology, v.54, p.1499-1515, 2000.

AMARAL, T.B.; CORREA, E.S.; COSTA, F.P. Aspectos econômicos do uso de touros melhoradores em um sistema de produção de gado de corte. In: REUNIÃO ANUAL DA SOCIEDADE BRASILEIRA DE ZOOTECNIA, 40., 2003, Santa Maria. Anais... São Paulo: Sociedade Brasileira de Zootecnia/Gmosis, [2003]. (CD-ROM).

BERETTA, V.; LOBATO, J.F.P.; MIELITZ NETO, C.G.A Produtividade e eficiência biológica de sistemas pecuários de cria diferindo na idade das novilhas ao primeiro parto e na taxa de natalidade do rebanho no Rio Grande do Sul. Revista Brasileira de Zootecnia, v.30, n.4, p.1278-1286, 2001.

BLACK, J.L.; DAVIES, G.T.; FLEMING, J.F. Role of computer simulation in the application of knowledge to animal industries. Australian Journal of Agricultural Research, v.44, p.541-555, 1993.

BLOCKEY, M.A.B. La fertilidad de los rodeos como factor de incremento de la fertilidad de los rodeos. Therios, suppl. 2, p.131-163, 1984. 
CHENOWETH, P.J. The economic impact of low fertility bulls. Feed Facts, v.12, p.1, 2002.

COLÉGIO BRASILEIRO DE REPRODUÇÃO ANIMAL, Manual para exame andrológico e avaliação de sêmen animal. 2.ed. Belo Horizonte, 1998. 49p.

FONSECA, V.O.; SANTOS, N.R.; MALINSKI, P.R. Classificação Andrológica de Touros Zebus (Bos taurus indicus) com base no perímetro escrotal e características morfo-físicas do sêmen. Revista Brasileira de Reprodução Animal, v.21, n.2, p.36-39, 1997.

FRANCO, C.S.; FONSECA, V.O.; GASTE, L. Potencial reprodutivo e econômico de touros Nelore acasalados coletivamente na proporção de um touro para 100 vacas. Arquivo Brasileiro de Medicina Veterinária e Zootecnia, v.58, n.6, p.1156-1161, 2006.

FONSECA, V.O.; FRANCO, C.S.; BERGMANN, J.A.G. Potencial Reprodutivo e econômico de touros Nelore acasalados coletivamente na proporção de um touro para 80 vacas. Arquivo Brasileiro de Medicina Veterinária e Zootecnia, v.52, n.1, p.77-82, 2000.

LAGERLOFF, N. Sterility and Bulls. The Veterinary Record, v.48, n.41, p.1159-1170, 1936.

LOPES, F.G.; GUIMARAES, J.D.; COSTA, E.P. et al.Avaliação andrológica por pontos e comportamento sexual em touros da raça Nelore. Revista Brasileira de Zootecnia, v.38, n.6, p.1018-1025, 2009.

MENEGASSI, S.R.O.; VIEIRA, M.I.B. Importância econômica da avaliação reprodutiva de touros. In: CONGRESSO ESTADUAL DE MEDICINA VETERINÁRIA, 17., 2006, Gramado. Anais... Gramado: Conselho Estadual de Medicina Veterinária, 2006. s/n.
MENEGASSI, S.R.O.; CANOZZI, M.E.A.; TEIXEIRA, J.L. et al. Causas físicas de descartes de touros no Rio Grande do Sul. In: CONGRESSO BRASILEIRO DE MEDICINA VETERINÁRIA, 35., 2008, Gramado. Anais... Gramado: Conselho Estadual de Medicina Veterinária, 2008. s/n.

MORAES, J.C.F.; HORN, M.M.; ROSADO JR., A.G. Exame andrológico em touros: qualidade dos indicadores da aptidão reprodutiva em distintos grupos raciais. Ciência Rural, v.28, p.647-652, 1998.

NORONHA, J.F. Projetos agropecuários: administração financeira, orçamento e viabilidade econômica. 2.ed. São Paulo: Atlas, 1987. 269p.

OLIVEIRA, B.D.F. Considerações técnico-econômicas da avaliação andrológica em sistemas de produção de rebanhos de corte. Revista do Conselho Federal de Medicina Veterinária, v.8, n.27, p.51-58, 2002.

PFEIFER,L.F.M.; SCHNEIDER, A.; NETO, J.W.S. et al. Avaliação biológica e economica do uso de flunixin meglumune em vacas e novilhas de corte inseminadas em tempo fixo. Revista Brasileira de Zootecnia, v.37, n.8, p.1392-1397, 2008.

SERENO, J.R.B.; SILVA, E.V.C.; MORES, C.M. Reduction of the Bull:cow ratio in the Brazilian Pantanal. Pesquisa Agropecuária Brasileira, v.32, n.12, p.1811-1817, 2002.

SILVA, J.F.; PEREIRA, D.A.S.; OLIVEIRA, J.F.C. et al. Avaliação da fertilidade potencial de touros. In: SIMPÓSIO NACIONAL DE REPRODUÇÃO ANIMAL, 4., 1981, Belo Horizonte. Anais... Belo Horizonte, 1981. supl.0, p.6.

TRENKLE, A.; WILLHAM, R.L. Beef Production Efficiency. Science, v.198, n.4321, p.1009-1015, 1997.

UNIVERSIDADE FEDERAL DO RIO GRANDE DO SUL - UFRGS. Diagnóstico de sistemas de produção de bovinocultura de corte do Estado do Rio Grande do Sul - Relatório 2005. Porto Alegre. 